Jurnal Tanah dan Air (Soil and Water Journal)

ISSN: 1411-5719(p): 2655-500X (e), Volume 16 Nomor 1 (Juni 2019): 43 - 54 (http://jurnal.upnyk.ac.id/index.php/ita/index)

\title{
PENDUGAAN EROSI DAN PEMETAAN TINGKAT BAHAYA EROSI DI DESA SAMBIREJO KECAMATAN PRAMBANAN KABUPATEN SLEMAN D.I. YOGYAKARTA
}

\section{(PREDICTION OF ACTUAL EROSION AND MAPPING OF EROSION HAZARD LEVEL AT SAMBIREJO PRAMBANAN SLEMAN D.I. YOGYAKARTA)}

\author{
Raina Nur Malinda ${ }^{1)}$, Dyah Arbiwati ${ }^{\left.2)^{*}\right)}$, dan S. Setyo Wardoyo ${ }^{2)}$ \\ ${ }^{1)}$ Prodi Agroteknologi, Universitas Pembangunan Nasional Veteran Yogyakarta \\ 2) Prodi Ilmu Tanah, Universitas Pembangunan Nasional Veteran Yogyakarta \\ ${ }^{*}$ Corresponding author E-mail: arbiarzl@gmail.com
}

\begin{abstract}
Soil erosion can be caused by some factors such as rain erosivity, soil erodibility, length slope, land use and land conservation. Sambirejo has a hilly topography with a type of slope from flat to extremely slope, many variety of slope will affect the runoff. Besides that, Sambirejo has many land use such as plantation, settlement, paddy field irrigation, rainfed paddy field, dry land, heath, bush and reservoir. The differences between land use and length slope will make a bigger risk for soil erosion if there isn't good land management. The aims of this research were to predict the actual erosion and analyze erosion hazard level. The USLE (Universal Soil Loss Equation) used to predict actual erosion and the classification for soil erosion hazard level used classification from the ministry of forestry (2013). The research method was used survey and the soil sampling method was used purposive. Based on the overlay of the slope map and land use map there are 16 land units. The measured parameters such as rain erosivity, soil erodibility, length slope, land use and land management. The result showed that the prediction of actual erosion with the highest level is $5.210,45 \mathrm{ton} / \mathrm{ha} / \mathrm{yr}(38,88 \mathrm{~cm} / \mathrm{yr})$ at moor with a steep slope and the lowest level is $6,96 \mathrm{ton} / \mathrm{ha} / \mathrm{yr}$ $(0,05 \mathrm{~cm} / \mathrm{yr})$ at rainfed paddy field with moderately steep. The level of erosion hazard level has light, medium, heavy and very heavy. Meanwhile, the percentage area of erosion hazard level at the light level is about $2,25 \%$, the medium level is $19,01 \%$, the heavy level is $4,32 \%$ and a very heavy level is $74,43 \%$.
\end{abstract}

\section{Keywords: Erosion, Erosion Hazard Level, USLE}

\begin{abstract}
ABSTRAK
Erosi dapat terjadi karena faktor erosivitas hujan, erodibitas tanah, kemiringan dan panjang lereng serta penggunaan lahan dan pengelolaan lahan. Desa Sambirejo termasuk dalam desa yang memiliki bentuk lahan yang berbukit-bukit dengan berbagai macam kemiringan mulai dari datar $(0-8 \%)$ hingga sangat terjal (>45\%). Kemiringan yang beragam akan mempengaruhi kecepatan aliran air permukaan. Selain itu Desa Sambirejo memiliki berbagai macam penggunaan lahan antara lain kebun atau perkebunan, permukiman, sawah irigasi, sawah tadah hujan, tegalan, rumput atau lahan kosong, semak belukar dan tubuh air. Pemanfaatan lahan yang berbeda-beda pada berbagai macam kemiringan lereng dapat memperbesar risiko terjadinya erosi apabila tidak didukung dengan pengelolaan lahan yang baik. Tujuan penelitian ini untuk mengetahui pendugaan erosi dan sebaran Tingkat Bahaya Erosi (TBE) di Desa Sambirejo. Perhitungan pendugaan erosi dihitung menggunakan metode USLE (Universal Soil Loss Equation) dan kelas TBE ditentukan berdasarkan tabel klasifikasi TBE menurut Kementrian Kehutanan (2013). Metode penelitian ini dilakukan dengan metode survey. Pengambilan sampel tanah dilakukan
\end{abstract}


dengan metode purposive berdasarkan overlay peta kemiringan lereng dan peta penggunaan lahan, sehingga diperoleh 16 satuan peta lahan. Parameter yang diukur antara lain erosivitas hujan, erodibilitas tanah, panjang lereng, kemiringan lereng, penggunaan lahan dan pengelolaan lahan. Hasil penelitian ini adalah pendugaan erosi tertinggi pada satuan lahan tegalan sangat terjal dengan nilai A sebesar 5.210,45 ton/ha/thn $(38,88 \mathrm{~cm} / \mathrm{thn})$ dan terendah nilai A sebesar 6,96 ton/ha/thn $(0,05 \mathrm{~cm} / \mathrm{thn})$ pada satuan lahan sawah tadah hujan terjal. Tingkat bahaya erosi (TBE) diperoleh kelas ringan, sedang, berat dan sangat berat, sedangkan persentase luasan TBE yaitu, ringan $2,25 \%$, sedang $19,01 \%$, berat $4,32 \%$ dan sangat berat sebesar $74,43 \%$.

Kata kunci: Erosi, TBE, USLE.

\section{PENDAHULUAN}

Erosi merupakan proses berpindahnya atau terangkutnya tanah dari satu tempat ke tempat lainnya akibat faktor alami. Proses erosi tersebut akan membawa tanah tersebut berpindah dan mengendap ditempat lain. Faktor alami yangdapat menyebabkan erosi adalah air dan angin. Indonesia memiliki iklim tropis basah sehingga sebagian besar erosi yang terjadi disebabkan oleh air. Terjadinya erosi dapat diprediksi besarannya dengan berbagai macam metode salah satunya adalah dengan metode USLE (Universal Soil Loss Equation) yang umum digunakan. Metode ini mempertimbangkan beberapa faktor yaitu: erosivitas hujan, erodibilitas tanah, panjang dan kemiringan lereng, vegetasi penutup tanah dan penggunaan lahan. Desa Sambirejo terletak di kecamatan Prambanan, Sleman, Yogyakarta dan memiliki total luas lahan sekitar $8,39 \mathrm{~km}^{2}$ dengan ketinggian wilayah kurang lebih $385 \mathrm{~m}$ dpl. Desa Sambirejo termasuk dalam desa yang memiliki bentuk lahan yang berbukit-bukit dengan berbagai macam kemiringan mulai dari datar (0 - 8\%) hingga sangat terjal $(>45 \%)$. Kemiringan yang beragam akan mempengaruhi kecepatan aliran air permukaan. Selain itu Desa Sambirejo memiliki berbagai macam penggunaan lahan antara lain kebun atau perkebunan, permukiman, sawah irigasi, sawah tadah hujan, tegalan, rumput atau lahan kosong, semak belukar dan tubuh air. Pemanfaatan lahan yang berbeda-beda pada berbagai macam kemiringan lereng dapat memperbesar risiko terjadinya erosi apabila tidak didukung dengan pengelolaan lahan yang baik.

\section{BAHAN DAN METODE}

Penelitian dilakukan di Desa Sambirejo Kecamatan Prambanan Kabupaten Sleman DI.Yogyakarta. Bahan yang digunakan yaitu peta kemiringan lereng, peta penggunaan lahan, data curah hujan bulanan, bahan kimia untuk analisis laboratorium serta sampel tanah dari masing-masing satuan lahan. Penentuan lokasi penelitian dengan metode purposive yaitu sengaja memilih Desa Sambirejo, Prambanan, Sleman, DI.Yogyakarta karena merupakan daerah yang mempunyai berbagai tingkat kemiringan dan penggunaan lahan. Penentuan satuan lahan didapatkan dari overlay peta kemiringan lereng dan penggunaan lahan dengan menggunakan Arc Gis 10.2. Hasil overlay peta kemiringan lereng dengan peta penggunaan lahan skala 1:17.000, disajikan pada gambar 1 . 


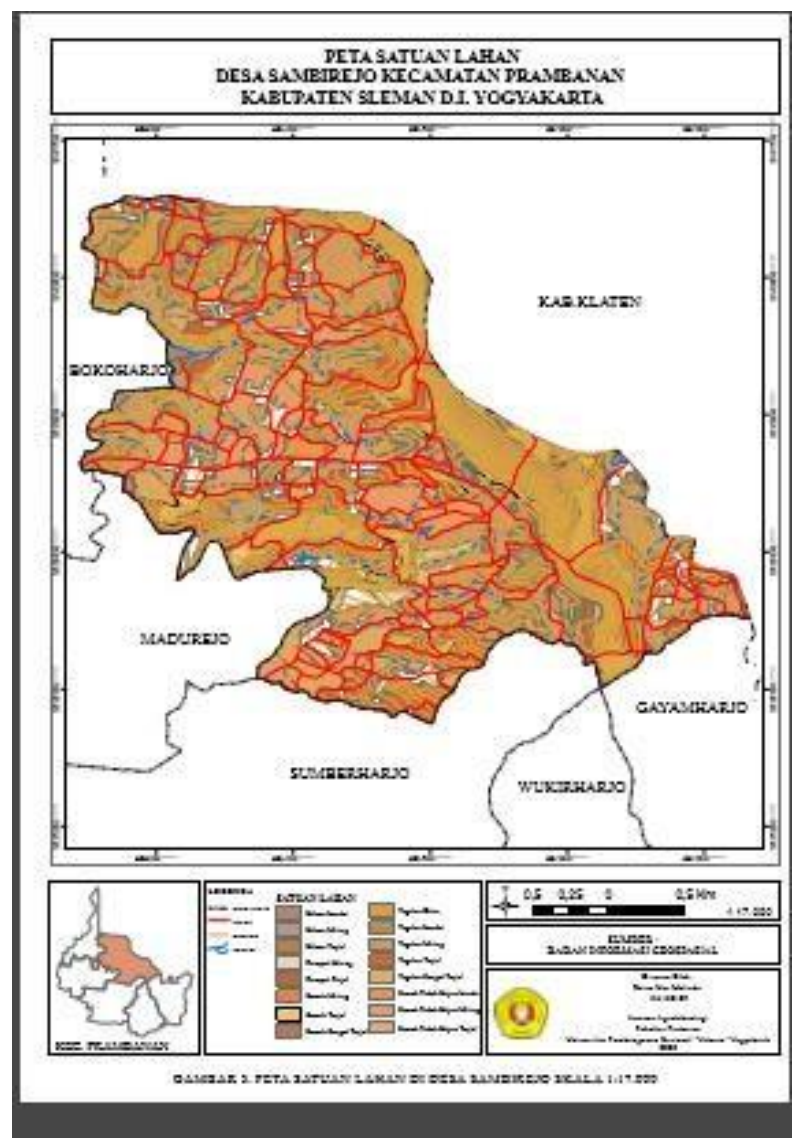

Gambar 1. Peta Satuan Lahan di Desa Sambirejo

Peta satuan lahan di Desa sambirejo diperoleh 31 satuan lahan tetapi ditentukan 16 satuan lahan untuk diambil sampel tanahnya (Tabel 1), dan pada masing-masing satuan lahan diambil 1 titik sampel.

Tabel 1. Koordinat Titik Sampel Pada Masing-masing Satuan Lahan Di Desa Sambirejo

\begin{tabular}{clcc}
\hline No & \multicolumn{1}{c}{ Satuan Lahan } & Koordinat $\mathbf{X}$ & Koordinat $\mathbf{Y}$ \\
\hline 1 & Tegalan Miring & 445.489 & 9.140 .688 \\
2 & Tegalan Datar & 444.208 & 9.140 .963 \\
3 & Tegalan Landai & 444.793 & 9.140 .914 \\
4 & Kebun Terjal & 444.690 & 9.139 .301 \\
5 & Kebun Miring & 444.669 & 9.139 .810 \\
6 & Sawah Tadah Hujan Miring & 446.342 & 9.139 .300 \\
7 & Kebun Landai & 444.645 & 9.139 .627 \\
8 & Rumput Miring & 445.865 & 9.138 .712 \\
9 & Rumput Terjal & 445.010 & 9.138 .968 \\
10 & Semak Miring & 446.399 & 9.139 .405 \\
11 & Semak Terjal & 445.938 & 9.140 .115 \\
12 & Sawah Tadah Hujan Landai & 445.222 & 9.140 .525 \\
13 & Sawah Tadah Hujan Terjal & 444.365 & 9.139 .418 \\
14 & Tegalan Terjal & 445.801 & 9.139 .498 \\
15 & Semak Sangat Terjal & 446.851 & 9.139 .222 \\
16 & Tegalan Sangat Terjal & 446.840 & 9.139 .675 \\
\hline
\end{tabular}


Metode pendugaan erosi yang digunakan adalah USLE (Universal Soil Loss Equation) dengan persamaan:

$\mathrm{A}=\mathrm{R} \times \mathrm{K} \times \mathrm{LS} \times \mathrm{C} \times \mathrm{P}$

Keterangan:

A : Banyaknya tanah tererosi (ton/ha/thn)

$\mathrm{R} \quad$ : Faktor curah hujan (Erosivitas)

K : Faktor erodibilitas tanah

LS : Faktor panjang dan kemiringan lereng

C : Faktor vegetasi penutup tanah dan pengelolaan tanaman

$\mathrm{P} \quad$ : Faktor tindakan-tindakan khusus konservasi tanah

Untuk menetapkan Tingkat Bahaya Erosi (TBE) dengan membandingkan hasil pendugaan erosi dengan kedalaman solum dan menggunakan tabel TBE menurut Kementrian Kehutanan (2013) yang disajikan pada Tabel 2.

Tabel 2. Tingkat Bahaya Erosi

\begin{tabular}{cccccc}
\hline \multirow{2}{*}{ Solum Tanah $(\mathbf{c m})$} & \multicolumn{5}{c}{ Erosi Maksimum (A) - ton/ha/thn } \\
\cline { 2 - 6 } & $<\mathbf{1 5}$ & $\mathbf{1 5 - 6 0}$ & $\mathbf{6 0 - 1 8 0}$ & $\mathbf{1 8 0 - 4 8 0}$ & $>\mathbf{4 8 0}$ \\
\hline$>90$ & $\mathrm{SR}$ & $\mathrm{R}$ & $\mathrm{S}$ & $\mathrm{B}$ & $\mathrm{SB}$ \\
$60-90$ & $\mathrm{R}$ & $\mathrm{S}$ & $\mathrm{B}$ & $\mathrm{SB}$ & $\mathrm{SB}$ \\
$30-60$ & $\mathrm{~S}$ & $\mathrm{~B}$ & $\mathrm{SB}$ & $\mathrm{SB}$ & $\mathrm{SB}$ \\
$<30$ & $\mathrm{~B}$ & $\mathrm{SB}$ & $\mathrm{SB}$ & $\mathrm{SB}$ & $\mathrm{SB}$ \\
\hline
\end{tabular}

\section{HASIL DAN PEMBAHASAN}

\section{Erosivitas Hujan}

Erosivitas hujan adalah kemampuan hujandalam menimbulkan erosi (Arsyad, 2010). Data curah hujan bulanan didapatkan dari Stasiun Klimatologi Yogyakarta dalam jangka waktu 10 tahun terakhir (2009-2018). Data curah hujan tersebut kemudian dihitung dengan rumus Lenvain (1989) dalam Christanto et al, (2010) sebagai berikut:

$\mathrm{Rm}=2,21 \mathrm{R}^{1,36}$

R: Curah hujan bulanan $(\mathrm{cm})$.

Dari hasil perhitungan diperoleh Erosivitas hujan di Desa Sambirejo sebesar1.770,22

\section{Erodibilitas Tanah}

Erodibilitas $(\mathrm{K})$ tanah adalah mudah tidaknya tanah mengalami erosi, yang di tentukan oleh beberapa sifat fisik dan kimia tanah. Faktor yang menentukan adalah tekstur tanah, bahan organik, struktur dan permeabilitas tanah. Kemudian dihitung dengan rumus Wischmeier (1971) sebagai berikut:

$$
100 \mathrm{~K}=1,292\left[2,1 \mathrm{M}^{1,14}\left(10^{-4}\right)(12-\mathrm{a})+3,25(\mathrm{~b}-2)+2,5(\mathrm{c}-3)\right]
$$

Keterangan:

$\mathrm{K}$ : erodibilitas; $\mathrm{M}$ : (\% debu $+\%$ pasir sangat halus) $\mathrm{x}(100-\%$ lempung); a: persen bahan organik; b: kelas struktur tanah; c: kelas permeabilitas 
Tabel 3. Nilai Erodibilitas Tanah Pada Masing-Masing Satuan Lahan Di Desa sambirejo

\begin{tabular}{clcc}
\hline No & \multicolumn{1}{c}{ Satuan Lahan } & $\mathbf{K}$ & Harkat \\
\hline 1. & Tegalan Miring & 0,50 & Tinggi \\
2. & Tegalan Datar & 0,28 & Sedang \\
3. & Tegalan Landai & 0,28 & Sedang \\
4. & Kebun Terjal & 0,40 & Agak Tinggi \\
5. & Kebun Miring & 0,43 & AgakTinggi \\
6. & Sawah Tadah Hujan Miring & 0,42 & AgakTinggi \\
7. & Kebun Landai & 0,31 & Sedang \\
8. & Rumput Miring & 0,50 & Tinggi \\
9. & Rumput Terjal & 0,51 & Tinggi \\
10 & Semak Miring & 0,53 & Tinggi \\
11. & Semak Terjal & 0,55 & Tinggi \\
12. & Sawah Tadah Hujan Landai & 0,41 & Agak Tinggi \\
13. & Sawah Tadah Hujan Terjal & 0,52 & Tinggi \\
14 & Tegalan Terjal & 0,31 & Sedang \\
15. & Semak Sangat Terjal & 0,45 & Tinggi \\
16. & Tegalan SangatTerjal & 0,59 & Sangat Tinggi \\
\hline
\end{tabular}

Nilai erodibilitas pada 16 titik sampel (Tabel 3), berkisar antara 0,28- 0,59. Keberagaman hasil yang didapatkan ditentukan oleh faktor tekstur tanah, bahan organik, struktur dan permeabilitas. Semakin tinggi nilai $\mathrm{K}$ yang dihasilkan menunjukkan semakin peka tanah tersebut terhadap erosi.

\section{Topografi}

Pendugaan erosi diperlukan data topografi yaitu panjang (L) dan kemiringan lereng (S). Faktor LS pada masing-masing satuan lahan disajikan pada Tabel 4.

Tabel 4. Faktor LS Pada Masing-Masing Satuan Lahan Di Desa Sambirejo

\begin{tabular}{clc}
\hline No. & \multicolumn{1}{c}{ Satuan Lahan } & LS \\
\hline 1 & Tegalan Miring & 7,89 \\
2 & Tegalan Datar & 3,97 \\
3 & Tegalan Landai & 4,99 \\
4 & Kebun Terjal & 9,86 \\
5 & Kebun Miring & 8,65 \\
6 & Sawah Tadah Hujan Miring & 6,34 \\
7 & Kebun Landai & 5,72 \\
8 & Rumput Miring & 5,21 \\
9 & Rumput Terjal & 18,13 \\
10 & Semak Miring & 7,32 \\
11 & Semak Terjal & 17,21 \\
12 & Sawah Tadah Hujan Landai & 3,24 \\
13 & Sawah Tadah Hujan Terjal & 18,91 \\
14 & Tegalan Terjal & 10,52 \\
15 & Semak Sangat Terjal & 11,91 \\
16 & Tegalan Sangat Terjal & 15,59 \\
\hline
\end{tabular}


Panjang lereng berpengaruh terhadap volume aliran permukaan yang berpindah. Semakin panjang lereng maka, volume air yang berpindah semakin besar dan tanah yang tererosi semakin banyak. Kemiringan lereng mempengaruhi kecepatan aliran permukaan dan kekuatan angkut partikel tanah oleh air. Makin besar nilai kemiringan lereng, maka kesempatan air untuk masuk kedalam tanah (infiltrasi) akan terhambat sehingga volume limpasan permukaan semakin besar yang mengakibatkan terjadinya bahaya erosi (Dewi et al., 2012).

\section{Vegetasi}

Faktor vegetasi penutup tanah dan pengelolaan tanaman (C) yaitu nisbah antara besarnya erosi dari suatu areal dengan vegetasi dan pengelolaan tanaman tertentu terhadap besarnya erosi dari tanah yang identik dan tanpa tanaman. Besarnya 0 sampai 1, tergantung dari tipe vegetasi, musim tanam dan teknik pengelolaan pertanian lainnya (Kodoatie dan Syarief, 2010). Faktor vegetasi pada masing-masing satuan lahan disajikan pada Tabel 5.

Tabel 5. Faktor Vegetasi Pada Masing-Masing Satuan Lahan Di Desa Sambirejo

\begin{tabular}{cccc}
\hline No & Satuan Lahan & Pengolahan Tanaman & C \\
\hline 1 & Tegalan Miring & Kebun Campuran Rapat & 0,1 \\
2 & Tegalan Datar & Kacang Tunggak & 0,161 \\
3 & Tegalan Landai & Kerapatan rendah dengan kacang tanah & 0,495 \\
4 & Kebun Terjal & Kebun Campuran Rapat & 0,1 \\
5 & Kebun Miring & Kebun Campuran Rapat & 0,1 \\
6 & Sawah Tadah Hujan Miring & Perladangan & 0,4 \\
7 & Kebun Landai & Kebun Campuran Rapat & 0,1 \\
8 & Rumput Miring & Rumput Bede (thn ke-1) & 0,278 \\
9 & Rumput Terjal & Kebun Campuran Rapat & 0,1 \\
10 & Semak Miring & Kebun Campuran Rapat & 0,1 \\
11 & Semak Terjal & Ubi Kayu & 0,8 \\
12 & Sawah Tadah Hujan Landai & Tanaman jagung dengan rumput gajah & 0,495 \\
13 & Sawah Tadah Hujan Terjal & Semak Tak Terganggu sebagian rumput & 0,01 \\
14 & Tegalan Terjal & Kebun Campuran Rapat & 0,1 \\
15 & Semak Sangat Terjal & Pohon Tanpa Semak & 0,32 \\
16 & Tegalan Sangat Terjal & Pohon Tanpa Semak & 0,32 \\
\hline
\end{tabular}

Hasil penelitian menunjukkan bahwa faktor vegetasi didominasi kebun campuran rapat. Faktor vegetasi tertinggi sebesar 0,8 yaitu vegetasi ubi kayu. Semakin besar nilai $\mathrm{C}$ maka vegetasi tersebut tidak efektif dalam pengendalian erosi. Hal ini dikarenakan tajuk daun tanaman ubi kayu tidak mampu mengurangi energi kinetik butir hujan menumbuk permukaan tanah dan batangnya tidak mampu mengurangi kecepatan aliran permukaan. Menurut Nur Saban (2006), Vegetasi dapat menghambat aliran permukaan dan memperbesar infiltrasi dan memperbesar infiltrasi, selain itu juga penyerapan air ke dalam tanah diperkuat oleh transpirasi (penyerapan air melalui vegetasi). 


\section{Pengelolaan Lahan}

Faktor tindakan-tindakan khusus konservasi tanah (P) yaitu nisbah antara besarnya erosi dari tanah yang diberi perlakuan tindakan konservasi khusus seperti pengolahan tanah menurut kontur, penanaman dalam strip atau teras terhadap besarnya erosi dari tanah yang diolah searah lereng dalam keadaan yang identik. Faktor pengelolaan lahan pada masing-masing satuan lahan di desa Sambirejo disajikan pada tabel 6 .

Tabel 6. Faktor Pengelolaan Lahan Pada Masing-Masing Satuan Lahan Di Desa Sambirejo

\begin{tabular}{cccc}
\hline No & Satuan Lahan & Tindakan Konservasi & P \\
\hline 1 & Tegalan Miring & Teras Bangku Konstruksi Sedang & 0,15 \\
2 & Tegalan Datar & Teras Bangku Konstruksi Baik & 0,04 \\
3 & Tegalan Landai & Teras Bangku Konstruksi Sedang & 0,04 \\
4 & Kebun Terjal & Terang Bangku Konstruksi Kurang Baik & 0,35 \\
5 & Kebun Miring & Teras Bangku Konstruksi Sedang & 0,15 \\
6 & Sawah Tadah Hujan Miring & Teras Bangku Konstruksi Sedang & 0,15 \\
7 & Kebun Landai & Teras Bangku Konstruksi Sedang & 0,15 \\
8 & Rumput Miring & Teras Bangku Konstruksi Sedang & 0,15 \\
9 & Rumput Terjal & Terang Bangku Konstruksi Kurang Baik & 0,35 \\
10 & Semak Miring & Teras Bangku Konstruksi Sedang & 0,15 \\
11 & Semak Terjal & Terang Bangku Konstruksi Kurang Baik & 0,35 \\
12 & Sawah Tadah Hujan Landai & Teras Bangku Konstruksi Baik & 0,04 \\
13 & Sawah Tadah Hujan Terjal & Teras Bangku Konstruksi Baik & 0,04 \\
14 & Tegalan Terjal & Terang Bangku Konstruksi & 0,35 \\
15 & Semak Sangat Terjal & Tanpa Tindakan Konservasi & 1 \\
16 & Tegalan Sangat Terjal & Tanpa Tindakan Konservasi & 1 \\
\hline
\end{tabular}

Pengelolaan lahan di Desa Sambirejo antara lain teras bangku baik, teras bangku sedang, dan teras bangku kurang baik. Semakin buruk konstruksi teras yang digunakan maka nilai $\mathrm{P}$ akan semakin besar. Pengelolaan lahan sangat berpengaruh terhadap laju aliran permukaan, apabila lahan tersebut memiliki konstruksi teras yang kurang baik, maka akan mempercepat aliran permukaan dan hasil pendugaan erosi menjadi lebih besar.

\section{Pendugaan Erosi Metode USLE}

Hasil pendugaan erosi dari 16 titik sampel tersebut kemudian di tentukan kelas erosinya menggunakan klasifikasi dari Kementrian Kehutanan 2013. Data pendugaan erosi pada masing-masing satuan lahan di Desa Sambirejo disajikan pada Tabel 7. 
R. N. Malinda, D. Arbiwati, dan S. S. Wardoyo: Pendugaan Erosi

Tabel 7. Pendugaan Erosi Pada Masing-Masing Satuan Lahan Di Desa Sambirejo

\begin{tabular}{cccc}
\hline No & Satuan Lahan & $\begin{array}{c}\text { A } \\
\text { (ton/ha/thn) }\end{array}$ & Kelas*) \\
\hline 1 & Tegalan Miring & 104,75 & III \\
2 & Tegalan Datar & 12,67 & I \\
3 & Tegalan Landai & 48,97 & II \\
4 & Kebun Terjal & 244,36 & IV \\
5 & Kebun Miring & 98,76 & III \\
6 & Sawah Tadah Hujan Miring & 282,82 & IV \\
7 & Kebun Landai & 47,08 & II \\
8 & Rumput Miring & 192,30 & IV \\
9 & Rumput Terjal & 572,88 & V \\
10 & Semak Miring & 103,02 & III \\
11 & Semak Terjal & 4691,68 & V \\
12 & Sawah Tadah Hujan Landai & 46,56 & II \\
13 & Sawah Tadah Hujan Terjal & 6,96 & I \\
14 & Tegalan Terjal & 202,06 & IV \\
15 & Semak Sangat Terjal & 3036,00 & V \\
16 & Tegalan Sangat Terjal & 5210,45 & V \\
\hline
\end{tabular}

Keterangan: I = Sangat Ringan; II = Ringan; III = Sedang; IV = Berat; V =Sangat Berat.

Pendugaan erosi di Desa Sambirejo didominasi oleh kelas erosi sangat berat. Hal ini dikarenakan faktor vegetasi dan pengelolaan lahan yang kurang baik serta didikung oleh lereng yang terjal. Pada satuan lahan tegalan sangat terjal memiliki nilai A yang paling tinggi yaitu 5.210,45 ton/ha/thn yang disebabkan oleh nilai $\mathrm{C}$ yang tinggi sebesar 0,32 dengan vegetasi pohon tanpa semak dan faktor P sebesar 1 tidak ada upaya pengelolaan lahan. Upaya untuk mengurangi erosi adalah menanam tanaman penutup tanah dengan pola strip pada tanaman utama. Hasil penelitian Sinukaban (2007) menyatakan bahwa efektivitas strip rumput vetiver atau akar wangi dalam mengurangi erosi dan aliran permukaan terlihat pada musim tanam kedua. Pada perlakuan lebar strip 3, 6 dan 9 baris tanaman dapat menekan aliran permukaan berturut - turut sebesar 30,5 \%, 29,8\% dan 35,7\% dan menurunkan erosi sebesar $51,5 \%, 35,4 \%$ dan 42,3\% dibanding tanpa strip akar wangi. Selain itu, Sinukaban (2007) menyatakan bahwa besarnya penurunan erosi akibat peningkatan penutupan mulsa jerami sebanyak 30\%, 60\% dan $90 \%$ adalah berturut - turut sebanyak $21 \%$, $62 \%$ dan $66 \%$. Fungsi mulsa jerami tersebut adalah mampu melindungi tanah dari timbunan energi hujan yang jatuh sehingga sedikit butiran tanah yang terdispersi dan tersedia untuk terbawa aliran air. Tindakan konservasi untuk menurunkan nilai erosi di daerah yang mempunyai lereng terjal adalah dengan membuat teras bangku konstruksi sedang atau baik. Sebaliknya pada satuan lahan sawah tadah hujan terjal dengan nilai A sangat rendah sebesar 6,96 ton/ha/thn. satuan lahan ini memiliki nilai $\mathrm{C}$ yang sangat rendah yaitu 0,01 dengan vegetasi semak tak terganggu sebagian rumput dengan pengelolaan lahan menggunakan teras bangku baik dengan nilai $\mathrm{P}$ sebesar 0,04 . 


\section{Tingkat Bahaya Erosi (TBE)}

Hasil tingkat bahaya erosi didapatkan dengan membandingkan antara nilai pendugaan erosi (A) dengan kedalaman solum. Kedalaman solum didapatkan dengan mengukur langsung dilapangan. Klasifikasi Tingkat Bahaya Erosi mengacu dari Kementrian Kehutanan (2013), disajikan pada Tabel 8.

Tabel 8. Kelas Tingkat Bahaya Erosi

\begin{tabular}{cccccc}
\hline Solum Tanah & \multicolumn{5}{c}{ Erosi Maksimum $(\mathbf{A})-$ ton/ha/thn } \\
\hline$(\mathrm{cm})$ & $<15$ & $15-60$ & $60-180$ & $180-480$ & $>480$ \\
$>90$ & $\mathrm{SR}$ & $\mathrm{R}$ & $\mathrm{S}$ & $\mathrm{B}$ & $\mathrm{SB}$ \\
$60-90$ & $\mathrm{R}$ & $\mathrm{S}$ & $\mathrm{B}$ & $\mathrm{SB}$ & $\mathrm{SB}$ \\
$30-60$ & $\mathrm{~S}$ & $\mathrm{~B}$ & $\mathrm{SB}$ & $\mathrm{SB}$ & SB \\
$<30$ & $\mathrm{~B}$ & $\mathrm{SB}$ & $\mathrm{SB}$ & $\mathrm{SB}$ & $\mathrm{SB}$ \\
\hline
\end{tabular}

Harkat Tingkat Bahaya Erosi pada masing-masing satuan lahan di Desa Sambirejo disajikan pada Tabel 9.

Tabel 9. Tingkat Bahaya Erosi Pada Masing-Masing Satuan Lahan Di Desa Sambirejo

\begin{tabular}{clccc}
\hline No & Satuan Lahan & A (ton/ha/thn) & Solum Tanah(cm) & Kelas \\
\hline 1 & Tegalan Miring & 104,75 & 60 & SB \\
2 & Tegalan Datar & 12,67 & 80 & $\mathrm{R}$ \\
3 & Tegalan Landai & 48,97 & 82 & $\mathrm{~S}$ \\
4 & Kebun Terjal & 244,36 & 87 & SB \\
5 & Kebun Miring & 98,76 & 56 & SB \\
6 & Sawah Tadah Hujan Miring & 282,82 & 88 & SB \\
7 & Kebun Landai & 47,08 & 34 & $\mathrm{~B}$ \\
8 & Rumput Miring & 192,30 & 48 & SB \\
9 & Rumput Terjal & 572,88 & 70 & SB \\
10 & Semak Miring & 103,02 & 44 & SB \\
11 & Semak Terjal & 4691,68 & 117 & SB \\
12 & Sawah Tadah Hujan Landai & 46,56 & 48 & B \\
13 & Sawah Tadah Hujan Terjal & 6,96 & 55 & S \\
14 & Tegalan Terjal & 202,06 & 78 & SB \\
15 & Semak Sangat Terjal & 3036,00 & 86 & SB \\
16 & Tegalan Sangat Terjal & 5210,45 & 102 & SB \\
\hline
\end{tabular}

Keterangan: SR=Sangat Ringan; R=Ringan; $\mathrm{S}=$ Sedang; $\mathrm{B}=\mathrm{Berat} ; \mathrm{SB}=$ Sangat Berat

Tingkat bahaya erosi (TBE) di Desa Sambirejo didominasi oleh kelas sangat berat, hal ini disebabkan kedalaman solum tanah yang dangkal meskipun erosinya rendah, sehingga apabila solum tanah dangkal mengalami erosi maka termasuk dalam kelas tingkat bahaya erosi yang sangat berat. 
R. N. Malinda, D. Arbiwati, dan S. S. Wardoyo: Pendugaan Erosi

Tabel 10. Persentase Luasan Tingkat Bahaya Erosi di Desa Sambirejo

\begin{tabular}{cccc}
\hline No & Kelas & Luasan (Ha) & Persentase Luasan (\%) \\
\hline 1 & Sangat Ringan & 0 & 0 \\
2 & Ringan & 16,28 & 2,25 \\
3 & Sedang & 137,64 & 19,01 \\
4 & Berat & 31,26 & 4,32 \\
5 & Sangat Berat & 539,00 & 74,43 \\
& & 724,18 & 100,00 \\
\hline
\end{tabular}

\section{Sebaran Tingkat Bahaya Erosi}

Penelitian yang telah dilakukan menunjukkan bahwa dari keseluruhan satuan lahan terdapat 4 kelas tingkat bahaya erosi dengan luasan yang berbeda - beda, disajikan dalam Tabel 10 dan peta tingkat bahaya erosi disajikan pada gambar 2 . Tingkat bahaya erosi di Desa Sambirejo luasan terbesar yaitu kelas sangat berat dengan luasan lahan 539 ha atau 74,43\% dari keseluruhan daerah.

\section{KESIMPULAN}

1. Pendugaan erosi dengan metode USLE di Desa Sambirejo, didapatkan hasil pendugaan erosi terendah pada satuan lahan sawah tadah hujan terjal dengan nilai A sebesar 6,96 ton/ha/thn. Hasil pendugaan erosi tertinggi pada satuan lahan tegalan sangat terjal dengan nilai A sebesar 5.210,45 ton/ha/thn.

2. Persebaran tingkat bahaya erosi di Desa Sambirejo yang disajikan berupa peta memiliki 4 kelas tingkat bahaya erosi, yaitu ringan, sedang, berat dan sangat berat. Sedangkan, Persentase luasan kelas tingkat bahaya erosi tersebut yaitu, ringan $2,25 \%$, sedang $19,01 \%$, berat $4,32 \%$ dan sangat berat sebesar $74,43 \%$. 


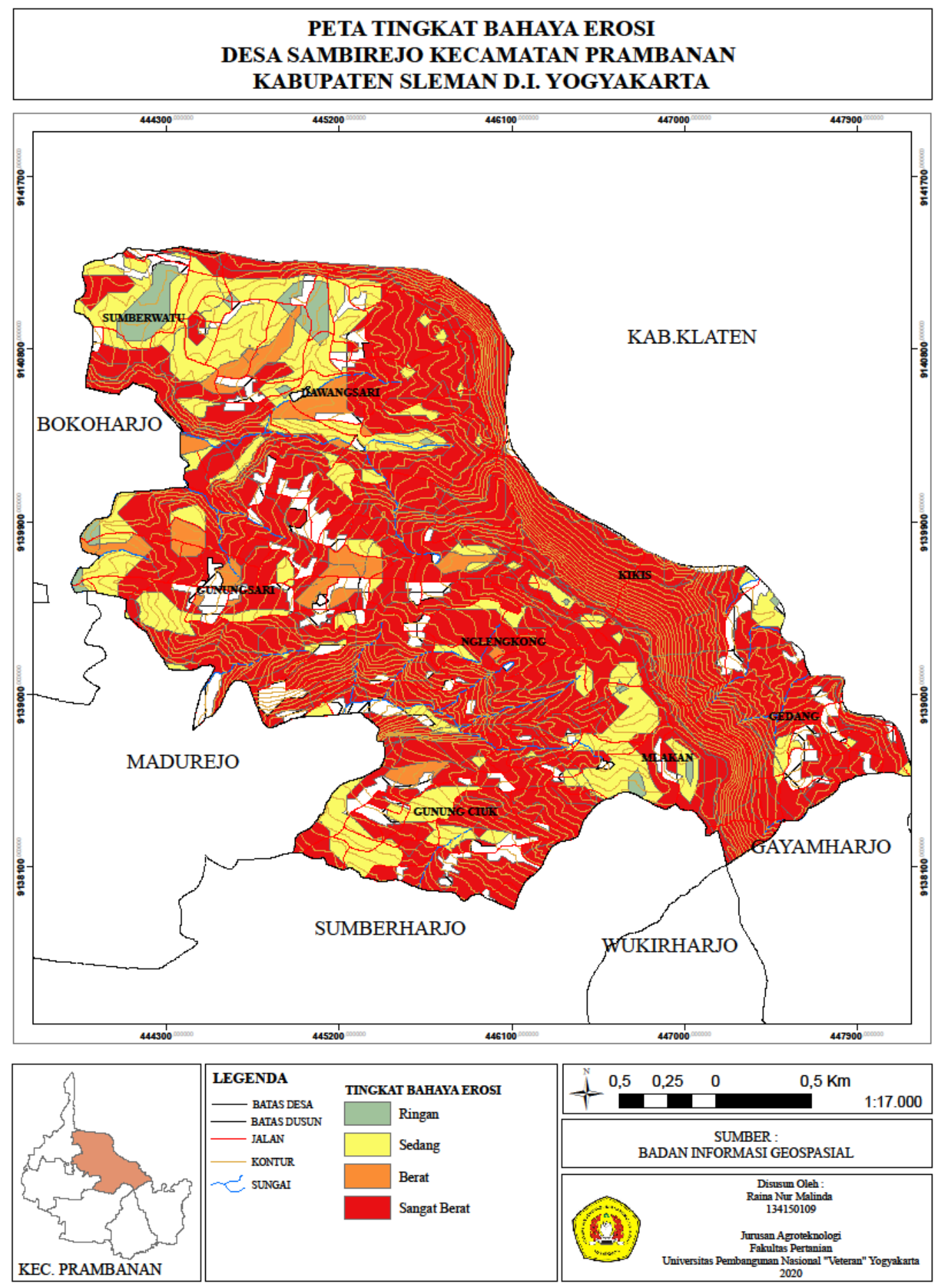

Gambar 2. Peta Tingkat Bahaya Erosi di Desa Sambirejo 


\section{DAFTAR PUSTAKA}

Arsyad, S. 2010. Konservasi Tanah dan Air. IPB Press. Bogor.

Christanto, R.E., Suryono., Mujoyo., Winarno, J. 2010. Pemetaan Tingkat Bahaya Erosi Lahan Kering Di Kecamatan Jatipuro Kabupaten Karanganyar dengan Sistem Informasi Geografi (SIG). Jurnal Ilmu Tanah dan Agroklimatologi 7 (2): 117122

Dewi, I.G.A.S.U., N. M. Trigunasih, T. Kusmawati. 2012. Prediksi Erosi dan Perencanaan Konservasi Tanah dan Air Pada Derah Aliran Sungai Saba. EJurnal Agroekoteknologi Tropika, Universitas Udayana, Bali.

Hardjowigeno S, Sukmana S. 1995. Menentukan tingkat bahaya erosi. Centre for Soil and Agroclimate Research. Bogor. $42 \mathrm{Hal}$

Kodoatie, R.J., Syarief, R. 2010. Tata Ruang Air. Andi Offset. Yogyakarta.

Nur Saban, M. 2006. Pengendalian Erosi Tanah Sebagai Upaya Melestarikan Kemampuan Fungsi Lingkungan. Geomedia, Yogyakarta. Vol. IV. No. 4:2.

Schwab. G.O., Richard. Frevert, Talcott. W. Edminster, Kenneth. K. Barnes. 1981. Soil and Water Conservation Engineering. Third Edition. John Willey and Sons New York. Chichester. Brisbone Toronto.

Sinukaban. 2007. Konservasi tanah dan air dalam pengendalian erosi dan rehabilitasi lahan. Pusat Penelitian dan Pengembangan Tanah dan Agroklimat. Bogor 